Limnol. Rev. (2016) 16, 3: 129-140

\title{
The impact of helophyte transpiration on vertical water exchange in water bodies
}

\author{
Katarzyna Grabowska ${ }^{1}$, Dariusz Borowiak ${ }^{1,2}$, Kamil Nowiński ${ }^{1}$ \\ ${ }^{1}$ Department of Limnology, University of Gdańsk, Bażyńskiego 4, 80-309 Gdańsk, Poland, \\ e-mail: geokasia@phdstud.ug.edu.pl (corresponding author),geodb@univ.gda.pl,geokamil@univ.gda.pl
}

${ }^{2}$ Limnological Station in Borucino, University of Gdańsk, 83-323 Kamienica Szlachecka, Poland, e-mail: geodb@univ.gda.pl

\begin{abstract}
The article presents the results of experimental research on evapotranspiration and transpiration of a common reed bed. The study was conducted in 2014-2015 on Lake Raduńskie Górne (Kashubian Lakeland) in the summer half-year from 1 May to 31 October. In the experiment two sets of standard evaporimeters GGI-3000 were used. One of the evaporimeters was filled with water, while the second additionally contained common reed. During the experiment medium reed bed density was 240 shoots per square metre. The results of the study showed that during the research period the average daily common reed transpiration was $3.9 \mathrm{~mm}$, and the daily maxima reached 12.1-12.5 mm. Average monthly transpiration totals ranged from 42.8 (October) to $208.5 \mathrm{~mm}$ (August). During the growing season, the loss of water to transpiration reached $872-971 \mathrm{~mm}$. The average transpiration rate, determined in the conditions of already well developed reed bed (June-September), was $1.83 \mathrm{dm}^{3} \mathrm{~m}^{-2} \mathrm{~d}^{-1}$. The values of the ratios $T_{h} / E_{O}$ and $E T_{h} / E_{O}$, determined during the experiment, were within the ranges reported in most previous research. The average ratio $T_{h} / E_{O}$ was 1.6 , and the ratio $E T_{h} / E_{O}$ was 2.0 . These values indicate that during the vegetation period common reed transpiration is higher by $60 \%$ from open water evaporation, and the total water losses from the common reed bed to evapotranspiration are twice as high as water loss in open water evaporation.
\end{abstract}

Key words: evaporation, evapotranspiration, transpiration, common reed, aquatic macrophytes

\section{Introduction}

Determining the components of lake water balance is a complex task. Firstly, this is due to the need to take into account a large number of elements of water supply and outflow and, secondly, the difficulty of accurately determining the real value of some of these balance elements using field methods (Choiński 2007). In the case of lakes whose surface is also covered with emergent vegetation, determining the balance component relating to water lost to evaporation can be subject to considerable error resulting from its underestimation or failure to include emergent vegetation transpiration.

The role of the reed bed in shaping lake water balance turns out to be extremely important considering that over $99 \%$ of the 300 million lakes on Earth (Downing et al. 2006) have an extensive littoral zone (over $99 \%$ of the lake surface), representing a potential macrophyte habitat (Wetzel 2001). Moreover, following limnological succession, modified by the various forms of human activity, a constant increase in the share of the littoral zone in the total lake surface is observed. Research on changes in lake surface in Poland prove that the dominant process leading to the natural disappearance of lakes is their overgrowing from the shores (Pieńkowski and Kuprec 2001; Ławniczak 2010; Ptak 2013). Decrease in the open water area is accompanied by the invasion of macrophytes and an increase in the area occupied by reed bed. The only comprehensive data available on which to base an assessment of the overgrowing rate of Poland's lakes is the documentation of the Inland Fisheries Institute in Olsztyn dating from the years 1950-1960 (IRS, unpublished). Structured data for nearly 900 lakes indicate that at that time emergent vegetation covered $4.1 \%$ of their surface. The overgrowth coefficient ranged from 2.8 (Pomeranian Lakeland) to $7.3 \%$ (Greater Poland-Kuyavian Lakeland) (Kowalczyk 1993). On the other hand, Ławniczak (2010) showed that in the last 50 years the surface area occupied by emergent vegetation of Lakes Nie- 
pruszowskie and Tomickie (Greater Poland Lakeland) increased by, respectively, over 170 and $414 \%$.

Water loss due to transpiration of water plants was first tested in the first half of the last century. Otis (1914) showed that evaporation from the vegetated water surface $\left(E T_{h}\right)$ is much greater than from the open surface $\left(E_{O}\right)$. The author calculated that plant evaporating power $\left(E T_{h} / E_{O}\right)$ ranges from 0.86 (water lily) to 3.05 (cattail). Similar conclusions were drawn by Kuznecov (1949: cited by Uryvaev 1953), who stated that the loss of water from a helophyte-covered surface is 1.5-2.5 times greater than evaporation from open water. Similar ratios of $E T_{h} / E_{O}$ were also mentioned by Kiendl (1953), Gelboukh (1963), and Herbst and Kappen (1999). The research by Šmid (1975) and Price (1994) showed that evapotranspiration from reedcovered surface is similar to open water evaporation, and the ratios of $E T_{h} / E_{O}$ are, respectively, 1.03 and 0.97 . Measurements of evapotranspiration of aquatic plants related to Poland's climatic conditions were conducted in the years 1971-1973 in Mikołajki (Bernatowicz et al. 1976) and in 2005-2011 in Radzyń (Rösler et al. 2012). The results of these studies also indicate increased vegetated water evaporation and in the summer half-year helophyte evaporating power ranges from 1.6 to 3.5 (Rösler et al. 2012). A large range of variation of the ratio $E T_{h} / E_{O}$ given in the literature stems from different evapotranspiration measuring techniques (lysimeter, evaporimeter, Bowen ratio, water balance), methods for calculating reference evaporation $\left(E_{O}\right)$, species composition as well as development of aquatic plants and weather conditions.

Accordingly, following the overgrowing process of lakes and relatively high evaporating power of aquatic plants, it is expected to record an increased share of transpiration of helophytes in the total water loss to evaporation, as well as in the overall lake water balance.

In order to verify the research hypothesis which assumes that helophytes significantly affect the increase of water losses due to atmospheric exchange, empirical studies were undertaken aimed to determine the difference in evaporation from open water and common reed-covered water (Phragmites australis (Cav.) Trin. ex Steud.). The results of evaporation and transpiration measurements collected during the experiment were used to: (i) estimate the transpiration rate of common reed, the dominant species of the lake rush zone in Poland, (ii) calculate the transpiration rate of common reed, and (iii) determine practical empirical relationships between reed bed evapotranspiration and open water evaporation in lakes adapted to the climatic conditions of the Kashubian Lakeland.

\section{Study area}

Field research on the transpiration of macrophytes was conducted at the Limnological Station of the University of Gdańsk in Borucino. The station is

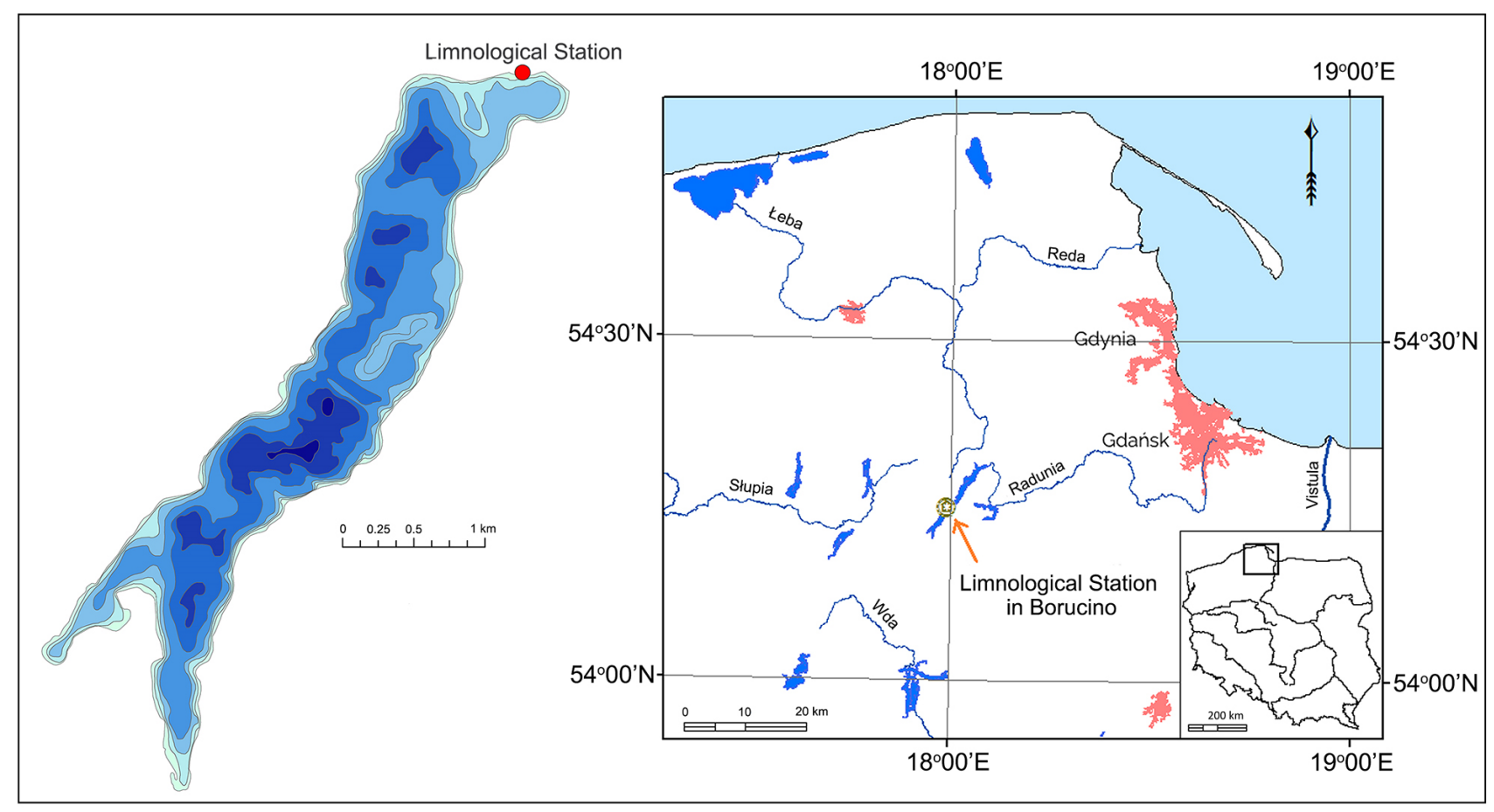

Fig. 1. Location of the Limnological Station in Borucino 
located in the eastern part of the Kashubian Lakeland, on the northern shore of Lake Raduńskie Górne (Fig. $1)$. Borucino is a third order climatologic station with a barometer, where measurements are performed three times a day. A traditional weather station, functioning there since 1959, it was equipped with an automatic weather station Vaisala MILOS-500 in 2005. The location of the weather station $\left(54^{\circ} 15^{\prime} \mathrm{N}, 17^{\circ} 59^{\prime} \mathrm{E}\right.$; geodetic elevation: $163 \mathrm{~m}$ a.s.l.) has remained unchanged from the beginning of its operation.

Borucino is one of the few weather stations in Poland which carries out continuous evaporimetric measurements. The station has an evaporimetric basin of $20 \mathrm{~m}^{2}$ and two evaporimeters GGI 3000 with an area of $3000 \mathrm{~cm}^{2}$. One of them is placed on land, while the other one, called the "floating evaporimeter", is mounted on a raft. The evaporimetric raft is anchored in Łączyno Bay about 200 metres from the lakeshore.

In terms of climatic regions of Poland, based on the frequency of certain types of weather, Borucino station is located within the region of the Eastern Pomerania (Woś 1999). This region has a mean annual air temperature of approximately $7.5^{\circ} \mathrm{C}$, while the annual temperature range reaches $18.8^{\circ} \mathrm{C}$. In the summer half-year when evaporation is measured, average temperature in Borucino is $13.4^{\circ} \mathrm{C}(1961-2015)$. The multiannual average of other climate parameters for the summer half-year are: precipitation - $398 \mathrm{~mm}$; atmospheric pressure $-989.4 \mathrm{hPa}$, relative humidity $-78.4 \%$, vapour pressure $-12.1 \mathrm{hPa}$, vapour pressure deficit $-3.5 \mathrm{hPa}$.

\section{Methods}

The essential part of the field experiments conducted in the years 2014-2015 were measurements of open water evaporation as well as evapotranspiration from the water surface and the rushes growing on it. The measuring set included two evaporimeters GGI 3000 . One of them was filled with water, while the other - also filled with water - was overgrown with common reed (Phragmites australis (Cav.) Trin. Ex Steud.). The average vegetation density during the experiment was 240 shoots per square metre.

The measuring set was placed in the south-eastern part of the weather station, at such a distance from the other measuring instruments and other fixed objects as to allow free air flow over the evaporating surface and its full exposure to solar radiation.

Evaporation, evapotranspiration and precipitation measurements (the latter necessary to correct the measured values) were performed in the summer-half year from 1 May to 31 October. Readings were performed twice a day at 06:00 and 18:00 UTC. The values of daily evaporation and evapotranspiration were the sums of the period from 18:00 on the previous day to 18:00 on a given day.

The characteristics of meteorological conditions of the measurement period were based on the data recorded by the automatic weather station MILOS-500. These data include average hourly values: air temperature, relative humidity, wind velocity, atmospheric pressure and total precipitation. To determine water vapour pressure and water vapour pressure deficit standard psychrometric tables were used (Rojecki 1959).

The overall thermal and pluvial characteristics of the measurement periods as well as climatic classification of individual months were based on the scale intervals defined by specific percentile values (Miętus et al. 2002; Miętus et al. 2005).

Every 2-3 weeks, the total leaf surface of all the reed shoots growing on the evaporimeter was calculated. The surface of a single leaf was based on its three linear dimensions, i.e. the length, maximum width and width measured in the middle of the leaf. For calculations the environment of MATLAB R2013a was used. The programme implemented four interpolation and polynomial approximation methods (maximum of level $n-1$, where $n$ is the number of known points). Finally, the method adopted as reliable was the one in which confidence level of the result obtained by numerical calculations exceeded $95 \%$. The function most accurately reflecting the leaf surface was approximation (nearly $99 \%$ conformity). The measured areas were subject to constant error independent of the measurement data.

To isolate the evapotranspiration component (ET) relating to water evaporation from among the plants $\left(E_{h}\right)$, a complementary experiment was carried out in 2016. The measuring set was supplemented by a third evaporimeter GGI 3000. In this one reed was planted and the water surface was covered with a layer of liquid paraffin 4-5 mm thick. Comparison of the measurement results of the three evaporimeters showed that evaporation from among plants represents $46 \%$ of evaporation from open water $\left(E_{O}\right)$ measured in the vegetation-free evaporimeter. Thus, in the calculation of common reed transpiration $\left(T_{h}\right)$ the following formula was adopted:

$$
T_{h}(\text { reed })=E T_{h}(\text { reed })-E_{h}(\text { reed })=E T_{h}(\text { reed })-0.46 E_{O}
$$

where: $T_{h}$ (reed) denotes reed transpiration $[\mathrm{mm}]$, $E T_{h}($ reed $)$ - water loss from reed-covered water [mm], $E_{h}($ reed $)$ - evaporation from reed-covered water $[\mathrm{mm}]$, $E_{O}$ - open water evaporation (reference evaporation) $[\mathrm{mm}]$. 


\section{Results}

The warmest months of the measurement period were July $2014\left(20.1^{\circ} \mathrm{C}\right)$ and August $2015\left(19.7^{\circ} \mathrm{C}\right)$, both classified as very warm. The coldest month was October 2015 with an average monthly air temperature of $7.3^{\circ} \mathrm{C}$ - classified as thermally normal. In 2014 the coldest month was also October $\left(9.7^{\circ} \mathrm{C}\right)$, described as slightly warm (Table 1).

The highest precipitation totals were recorded in September 2015 (96.2 mm) and in May 2014 (86.8 $\mathrm{mm}$ ). Those months were classified as wet (Table 1). August 2015 was extremely dry, and the precipitation total was only $11.8 \mathrm{~mm}$. In 2014, the lowest precipitation, amounting to $33.2 \mathrm{~mm}$, was recorded in October (normal month in pluvial terms).

Average monthly relative humidity calculated for the measuring seasons ranged from 66.5 (August 2015) to $84.6 \%$ (October 2015). Average humidity in both seasons was similar and amounted to $75-76 \%$. Average monthly water vapour deficit varied from 1.7 (October 2015) to $8.7 \mathrm{hPa}$ (August 2015), and the average vapour pressure ranged from 8.8 (October 2015) to $16.6 \mathrm{hPa}$ (July 2014).

A detailed list of meteorological parameters for the entire measurement period is presented in Table 1 . In general, the measuring season of 2014 was anomalously warm and dry, while in 2015 it was slightly warm and dry.

Decade open water evaporation ranged from 5.2 (second decade of October 2014) to $42.7 \mathrm{~mm}$ (first dec- ade of June 2015) (Fig. 2). Indicators of irregularities of decade evaporation (ratio of standard deviation to the mean value) during the two measurement periods were very similar and ranged from 40 to $42 \%$, with greater irregularity in 2015. Lowest monthly open water evaporation was recorded in October $2014(27.7 \mathrm{~mm})$, while the highest in August 2015 (108.4 mm). Daily evaporation maxima amounted to 5.6 and $5.7 \mathrm{~mm}$, respectively, in 2014 and 2015.

Water losses from the reed-covered water surface were lowest in the last decade of October $2015(8.5 \mathrm{~mm})$, while the highest value was recorded in the second decade of August 2015 (108.3 mm) (Fig. 3). Decade evapotranspiration irregularity was greater than evaporation from the water surface. In 2014, the evapotranspiration irregularity coefficient was $47 \%$, while in the next year $55 \%$. October was the month in which the lowest evapotranspiration total was recorded $-51.2 \mathrm{~mm}$ in 2014 and $58.0 \mathrm{~mm}$ in 2015. Evapotranspiration reached the highest monthly value in August 2015 (304.2 mm), an extremely warm and extremely dry month (Table 1). In 2014 and 2015 daily evapotranspiration maxima were 14.7 and $14.9 \mathrm{~mm}$, respectively.

Common reed transpiration was the lowest in the last decade of October $2014(7.2 \mathrm{~mm})$, while the highest value $(88.9 \mathrm{~mm})$ was recorded in the second decade of August of the following year (Fig. 4). Decade transpiration variability proved to be the highest. The coefficients of irregularities were $50 \%$ in 2014 , and $60 \%$ in 2015 . As with the previously discussed characteristics, October was the month in which the smallest

Table 1. Average monthly and seasonal air temperature (AT), wind velocity (V), relative humidity (RH), atmospheric pressure (SLP), water vapour pressure (VP), water vapour pressure deficit (VPD) and total precipitation (PP) as well as thermal and pluvial characteristics of the test period

\begin{tabular}{|c|c|c|c|c|c|c|c|c|c|}
\hline \multicolumn{10}{|c|}{ Year 2014} \\
\hline Month & $\begin{array}{c}\text { AT } \\
{\left[{ }^{\circ} \mathrm{C}\right]}\end{array}$ & $\begin{array}{c}\mathrm{V} \\
{\left[\mathrm{m} \mathrm{s}^{-1}\right]}\end{array}$ & $\begin{array}{l}\mathrm{RH} \\
{[\%]}\end{array}$ & $\begin{array}{c}\text { SLP } \\
{[\mathrm{hPa}]}\end{array}$ & $\begin{array}{c}\mathrm{VP} \\
{[\mathrm{hPa}]}\end{array}$ & $\begin{array}{l}\text { VPD } \\
\text { [hPa] }\end{array}$ & $\begin{array}{c}\mathrm{PP} \\
{[\mathrm{mm}]}\end{array}$ & Thermal characteristics & Pluvial characteristics \\
\hline May & 12.0 & 2.2 & 73.3 & 995.9 & 10.4 & 4.5 & 86.8 & normal & wet \\
\hline June & 14.8 & 1.7 & 74.2 & 995.8 & 12.3 & 5.2 & 60.0 & normal & normal \\
\hline July & 20.1 & 1.9 & 72.2 & 995.8 & 16.6 & 7.4 & 61.6 & very warm & normal \\
\hline August & 16.9 & 2.3 & 73.7 & 992.7 & 14.0 & 5.9 & 54.0 & normal & normal \\
\hline September & 14.1 & 1.8 & 79.4 & 999.5 & 12.7 & 3.8 & 44.0 & very warm & normal \\
\hline October & 9.7 & 2.2 & 84.3 & 988.6 & 10.4 & 2.0 & 33.2 & very warm & normal \\
\hline May-October & 14.6 & 2.0 & 76.2 & 994.7 & 12.8 & 4.8 & 339.6 & anomalously warm & dry \\
\hline \multicolumn{10}{|c|}{ Year 2015} \\
\hline Month & $\begin{array}{c}\text { AT } \\
{\left[{ }^{\circ} \mathrm{C}\right]}\end{array}$ & $\begin{array}{c}\mathrm{V} \\
{\left[\mathrm{m} \mathrm{s}^{-1}\right]}\end{array}$ & $\begin{array}{l}\mathrm{RH} \\
{[\%]}\end{array}$ & $\begin{array}{l}\text { SLP } \\
{[\mathrm{hPa}]}\end{array}$ & $\begin{array}{c}\mathrm{VP} \\
{[\mathrm{hPa}]}\end{array}$ & $\begin{array}{c}\text { VPD } \\
{[\mathrm{hPa}]}\end{array}$ & $\begin{array}{c}\mathrm{PP} \\
{[\mathrm{mm}]}\end{array}$ & Thermal characteristics & Pluvial characteristics \\
\hline May & 11.0 & 2.3 & 71.7 & 995.0 & 9.2 & 4.2 & 34.0 & cool & dry \\
\hline June & 14.2 & 2.0 & 72.6 & 998.2 & 11.5 & 5.1 & 41.4 & slightly cool & normal \\
\hline July & 16.7 & 2.5 & 73.6 & 994.0 & 13.8 & 5.9 & 80.0 & slightly cool & normal \\
\hline August & 19.7 & 2.0 & 66.5 & 999.5 & 15.0 & 8.7 & 11.8 & extremely warm & extremely dry \\
\hline September & 13.5 & 1.8 & 81.4 & 998.3 & 12.5 & 3.4 & 96.2 & very warm & wet \\
\hline October & 7.3 & 1.9 & 84.6 & 1002.5 & 8.8 & 1.7 & 33.6 & slightly cool & normal \\
\hline May-October & 13.8 & 2.1 & 75.1 & 997.9 & 11.8 & 4.8 & 297.0 & slightly warm & dry \\
\hline
\end{tabular}




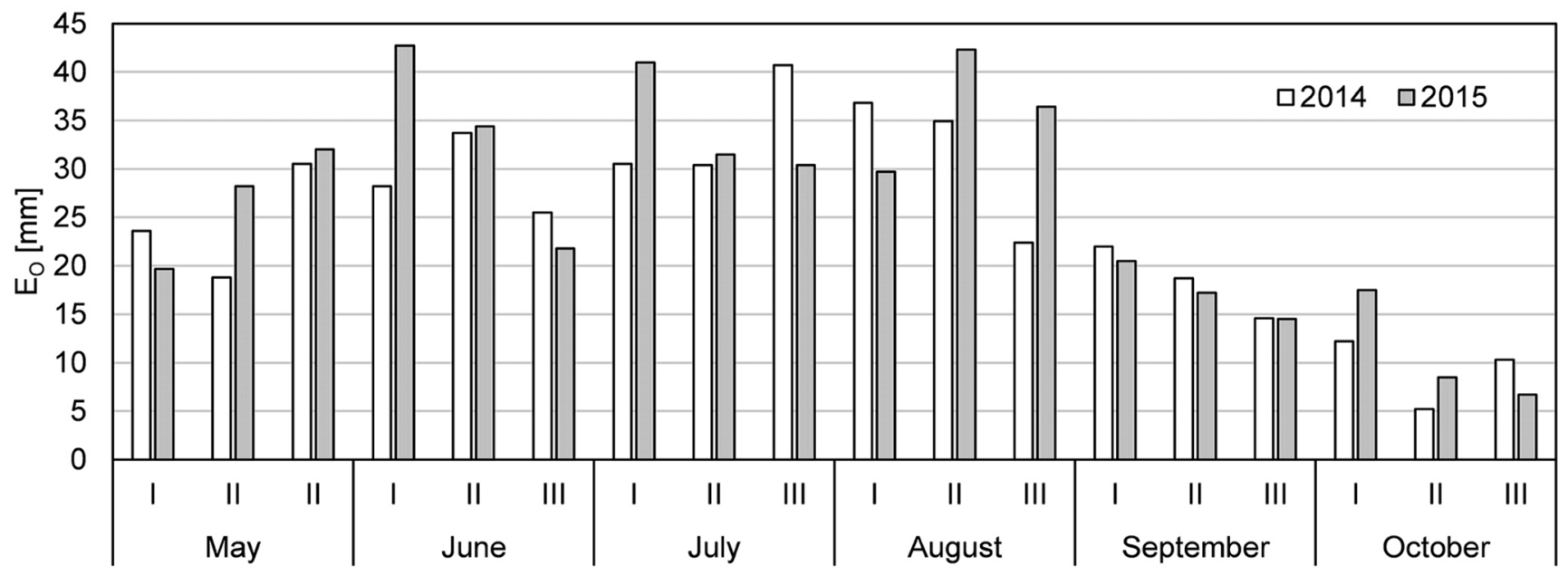

Fig. 2. Decade open water evaporation totals $\left(E_{O}\right)$ in the summer half-years of 2014 and 2015

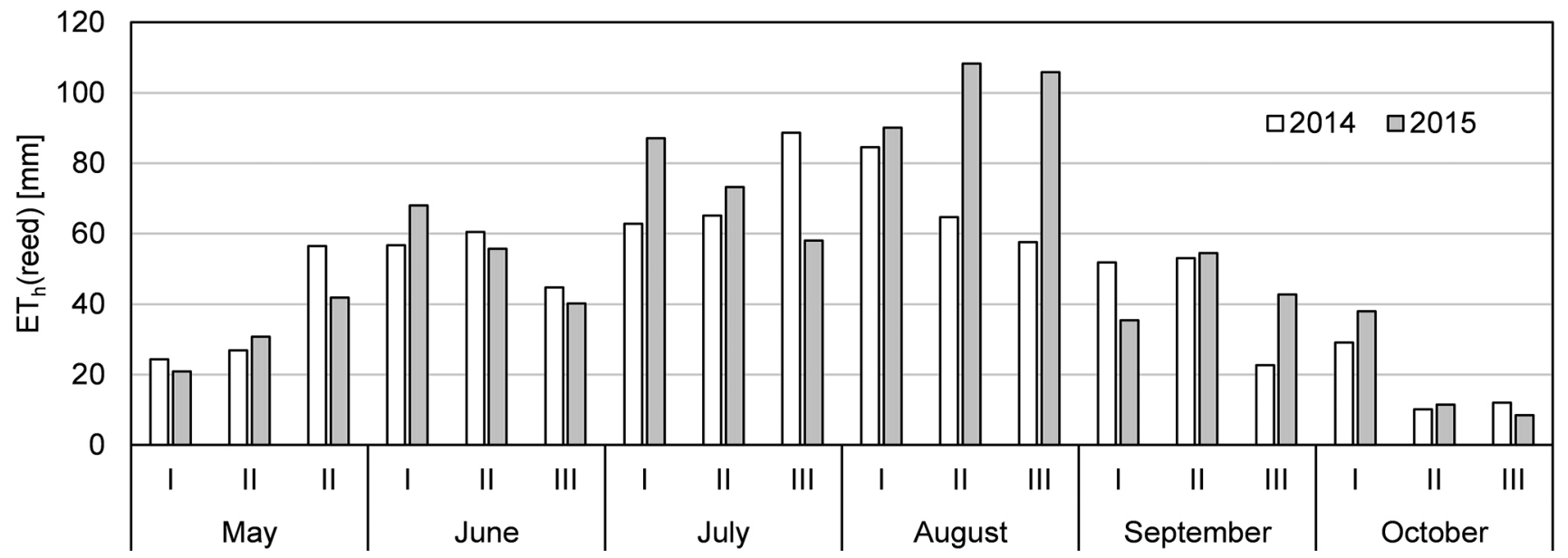

Fig. 3. Decade common reed evapotranspiration totals $\left(E T_{h}(\right.$ reed $\left.)\right)$ in the summer half-years of 2014 and 2015

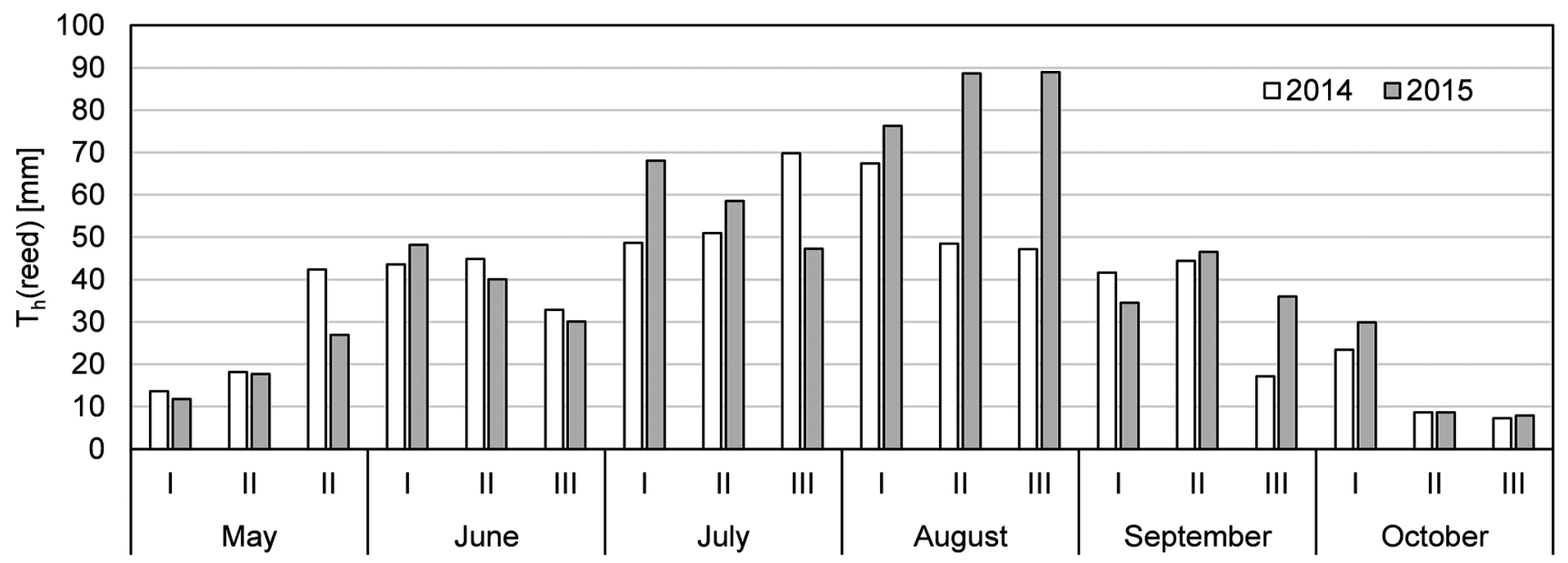

Fig. 4. Decade common reed transpiration totals (Th(reed)) in the summer half-years of 2014 and 2015 
transpiration totals were recorded $-39.3 \mathrm{~mm}$ in 2014 and $46.4 \mathrm{~mm}$ in 2015. Transpiration, like evapotranspiration, reached the highest monthly value $(253.9 \mathrm{~mm})$ in August 2015. Daily transpiration maxima in both seasons were similar -12.1 and $12.5 \mathrm{~mm}$, respectively, in 2014 and 2015.

Development of plant cover at the measuring site proceeded somewhat differently in both seasons. The warm spring of 2014 resulted in earlier reed vegetation. In May 2014, total leaf surface was over twice as high as in 2015. In 2014, maximum leaf area development took place in July, while in the following year - a month later.
In the period of maximum reed development the Leaf Area Index (LAI) was 3.25 and $3.99 \mathrm{~m}^{2} \mathrm{~m}^{-2}$, respectively, in 2014 and 2015. In both years average seasonal reed density at the site was similar and amounted to 230-260 live shoots per square metre. Greatest reed density was recorded in September 2015 (330 shoots per square metre), while the lowest density was observed in May 2014 (180 shoots per square metre). In both years, by the end of the growing season (October), only $20.6-32.9 \%$ of shoots were still living. The morphological characteristics of common reed at the measuring site in both research seasons are presented in Table 2 .

Table 2. Morphological characteristics of common reed in individual months of the measurement period in 2014 and 2015 , ${ }^{*}$ number of live shoots

\begin{tabular}{|c|c|c|c|c|c|c|c|}
\hline \multicolumn{8}{|c|}{ Year 2014} \\
\hline Month & $\begin{array}{l}\text { Number } \\
\text { of shoots }\end{array}$ & $\begin{array}{l}\text { Mean height of shoots } \\
\text { above water surface }[\mathrm{cm}]\end{array}$ & $\begin{array}{l}\text { Number of } \\
\text { leaves }\end{array}$ & $\begin{array}{c}\text { Area of } \\
\text { leaves }\left[\mathrm{cm}^{2}\right]\end{array}$ & $\begin{array}{l}\text { Mean length of } \\
\text { a leaf }[\mathrm{cm}]\end{array}$ & $\begin{array}{l}\text { Mean maximum } \\
\text { width of a leaf }[\mathrm{cm}]\end{array}$ & $\begin{array}{c}\text { LAl } \\
{\left[\mathrm{m}^{2} \mathrm{~m}^{-2}\right]}\end{array}$ \\
\hline May & 55 & 56.2 & 226 & 3358.8 & 18.4 & 1.2 & 1.12 \\
\hline June & 58 & 81.4 & 388 & 7097.5 & 19.9 & 1.2 & 2.37 \\
\hline July & 75 & 91.8 & 516 & 10035.0 & 22.3 & 1.3 & 3.35 \\
\hline August & 84 & 74.7 & 623 & 8216.7 & 17.8 & 1.0 & 2.74 \\
\hline September & 65 & 77.5 & 572 & 5710.2 & 15.3 & 0.9 & 1.90 \\
\hline October & $73 / 15^{*}$ & 37.4 & 42 & 289.8 & 11.4 & 0.9 & 0.10 \\
\hline May-October & 68 & 69.8 & 395 & 5784.7 & 17.5 & 1.1 & 1.93 \\
\hline \multicolumn{8}{|c|}{ Year 2015} \\
\hline Month & $\begin{array}{l}\text { Number } \\
\text { of shoots }\end{array}$ & $\begin{array}{l}\text { Mean height of shoots } \\
\text { above water surface }[\mathrm{cm}]\end{array}$ & $\begin{array}{l}\text { Number of } \\
\text { leaves }\end{array}$ & $\begin{array}{c}\text { Area of } \\
\text { leaves }\left[\mathrm{cm}^{2}\right]\end{array}$ & $\begin{array}{l}\text { Mean length of } \\
\text { a leaf }[\mathrm{cm}]\end{array}$ & $\begin{array}{l}\text { Mean maximum } \\
\text { width of a leaf }[\mathrm{cm}]\end{array}$ & $\begin{array}{c}\text { LAl } \\
{\left[\mathrm{m}^{2} \mathrm{~m}^{-2}\right]}\end{array}$ \\
\hline May & 59 & 41.9 & 180 & 1422.8 & 12.2 & 0.9 & 0.47 \\
\hline June & 61 & 63.0 & 245 & 4413.1 & 20.4 & 1.2 & 1.47 \\
\hline July & 82 & 85.7 & 535 & 9693.8 & 21.3 & 1.3 & 3.23 \\
\hline August & 96 & 78.0 & 752 & 11978.0 & 18.9 & 1.2 & 3.99 \\
\hline September & 99 & 81.7 & 870 & 10818.2 & 16.4 & 1.0 & 3.61 \\
\hline October & $70 / 23^{*}$ & 34.7 & 77 & 461.0 & 10.3 & 0.8 & 0.15 \\
\hline May-October & 78 & 64.2 & 443 & 6464.5 & 16.6 & 1.1 & 2.15 \\
\hline
\end{tabular}

Table 3. Monthly and seasonal average values of open water evaporation $\left(E_{O}\right)$, evapotranspiration $\left(E T_{h}\right)$, common reed transpiration $\left(T_{h}\right)$, evaporation from reed-covered water surface $\left(E_{h}\right)$, evapotranspiration to open water evaporation ratio $\left(E T_{h} / E_{O}\right)$, transpiration to open water transpiration ratio $\left(T_{h} / E_{O}\right)$ and transpiration rate $(T I)$

\begin{tabular}{|c|c|c|c|c|c|c|c|c|}
\hline Year & Month & $E_{o}[\mathrm{~mm}]$ & $E T_{h}[\mathrm{~mm}]$ & $T_{h}[\mathrm{~mm}]$ & $E_{h}[\mathrm{~mm}]$ & $E T_{h} / E_{o}$ & $T_{h} / E_{o}$ & $\begin{array}{c}\mathrm{TI} \\
{\left[\mathrm{dm}^{3} \mathrm{~m}^{-2} \mathrm{~d}^{-1}\right]}\end{array}$ \\
\hline \multirow{7}{*}{$\stackrel{\nabla}{\grave{N}}$} & May & 72.9 & 107.7 & 74.2 & 33.8 & 1.5 & 1.0 & 2.137 \\
\hline & June & 87.4 & 161.9 & 121.3 & 40.6 & 1.9 & 1.4 & 1.709 \\
\hline & July & 101.6 & 216.6 & 169.4 & 47.2 & 2.1 & 1.7 & 1.634 \\
\hline & August & 94.1 & 206.8 & 163.1 & 43.7 & 2.2 & 1.7 & 1.921 \\
\hline & September & 55.3 & 127.6 & 103.1 & 25.7 & 2.3 & 1.9 & 1.806 \\
\hline & October & 27.7 & 51.2 & 39.3 & 12.9 & 1.8 & 1.4 & 13.117 \\
\hline & May-October & 73.2 & 145.3 & 111.7 & 34.0 & 2.0 & 1.5 & 1.890 \\
\hline \multirow{8}{*}{$\stackrel{\llcorner}{\stackrel{2}{\sim}}$} & May & 79.9 & 93.5 & 56.4 & 37.1 & 1.2 & 0.7 & 3.837 \\
\hline & June & 98.9 & 163.9 & 118.3 & 45.9 & 1.7 & 1.2 & 2.680 \\
\hline & July & 102.9 & 218.3 & 173.9 & 47.8 & 2.1 & 1.7 & 1.736 \\
\hline & August & 108.4 & 304.2 & 253.9 & 50.3 & 2.8 & 2.3 & 2.051 \\
\hline & September & 52.2 & 132.6 & 117.0 & 24.2 & 2.5 & 2.2 & 1.081 \\
\hline & October & 32.7 & 58.0 & 46.4 & 15.2 & 1.8 & 1.4 & 9.737 \\
\hline & May-October & 79.2 & 161.8 & 127.6 & 36.7 & 2.0 & 1.6 & 1.931 \\
\hline & $2014-2015$ & 76,2 & 153.5 & 119.7 & 35.3 & 2.0 & 1.6 & 1.910 \\
\hline
\end{tabular}


The ratio of $E T_{h} / E_{O}$ ranged from 1.2 (May 2015) to 2.8 (August 2015). Its seasonal averages in individual years were identical (2.0) (Table 3). Temporal variability of the $T_{h} / E_{O}$ ratio referred to changes in the $E T_{h} / E_{O}$ ratio, but its values were reduced by an average of $24 \%$. The most notable differences between the ratios were observed in May (33-44\%), while the smallest differences were recorded in July and September (12-19\%).

The highest mean daily transpiration rate was observed in October, at 13.12 and $9.74 \mathrm{dm}^{3} \mathrm{~m}^{-2} \mathrm{~d}^{-1}$, respectively, in 2014 and 2015 (Table 3). These values correspond to an average hourly transpiration rate of 5.47 and $4.06 \mathrm{~g} \mathrm{dm}^{-2} \mathrm{hr}^{-1}$. In other months, the transpiration rate was lower and ranged from 1.08 (September 2014) to $3.84 \mathrm{dm}^{3} \mathrm{~m}^{-2} \mathrm{~d}^{-1}$ (May 2015). The average transpiration rate for the entire measurement period was 1.91 $\mathrm{dm}^{3} \mathrm{~m}^{-2} \mathrm{~d}^{-1}\left(0.80 \mathrm{~g} \mathrm{dm}^{-2} \mathrm{hr}^{-1}\right)$. The difference in the transpiration rate measured in different measurement seasons did not exceed $2.2 \%$ of the mean value determined for the entire study period.

\section{Discussion}

Transpiration and evapotranspiration rate depend on meteorological factors such as availability of solar energy, air temperature and humidity, wind velocity (Baier 1968; Hanami 1974; Sánchez-Carrillo et al. 2001), as well as plant species and their physical parameters (Devlin 1975; Snyder and Boyd 1987; Kacperska 2009).

Daily totals of transpiration and evapotranspiration measured in Borucino in the summer half-years of 2014 and 2015 showed a very strong, positive correlation with water vapour deficit and air temperature. These correlations were statistically significant, and the confidence level exceeded 95\% (Figs 5A, D and Figs 6A, D). These two parameters define the evaporation power of the atmosphere, and in waterlogged conditions and permanent availability of water for plants they determine biological evaporation rate. Slightly less marked but equally clear, was the influence of relative humidity (Fig. 5B, Fig. 6B). Since water vapour deficit is closely dependent on air temperature and its humidity, these three parameters shape the strongest evapotranspiration and transpiration rate. In many empirical models used to estimate water losses to evapotranspiration and/or transpiration, besides solar energy - a key factor in the size of these streams, the above meteorological parameters or combinations thereof are also commonly used (Sánchez-Carrillo et al. 2001; Chunpin et al. 2002).

Less manifested, however, was the impact of water vapour pressure on evapotranspiration $\left(\mathrm{R}^{2}=0.414\right.$; $\mathrm{p}<0.05)$ and transpiration $\left(\mathrm{R}^{2}=0.440, \mathrm{p}<0.05\right)$ (Fig. $5 \mathrm{C}$, Fig. $6 \mathrm{C}$ ). In addition, there was no statistically sig- nificant correlation between evapotranspiration/transpiration and wind velocity or atmospheric pressure (Fig. 5E-F, Fig. 6E-F). It is understood that both of these factors play an important role in the atmospheric water exchange. The wind, affecting the exchange rate of the residual air above the evaporating surface, shapes dynamic changes of water vapour content in the atmosphere. Atmospheric pressure determines the energy evaporating water molecules need to overcome in order to penetrate into the environment during diffusion (Malinowska 2010). Under the conditions of the experiment, these parameters were found to be secondary factors.

Consequently, the largest daily values of $E T_{h}$ and $T_{h}$ were observed in times of high water vapour deficit (greater than $7.0 \mathrm{hPa}$ ) and air temperature higher than $20^{\circ} \mathrm{C}$. In July 2014 and August 2015, when the monthly totals of $E T_{h}$ and $T_{h}$ were the highest, the average monthly water vapour deficits ranged from 7.4 to 8.7 $\mathrm{hPa}$, and average temperatures from 19.7 to $20.1^{\circ} \mathrm{C}$. The greatest daily loss of water to transpiration $(>12 \mathrm{~mm}$ $\mathrm{d}^{-1}$ ) was observed when the air temperature exceeded $23^{\circ} \mathrm{C}$, and the water vapour deficit was more than 14.0 $\mathrm{hPa}$. Average and maximum daily $T_{h}$ values found during the experiment correspond well to the values found for other areas located in the temperate climate zone (Table 4).

The lowest monthly, decade and decade and daily values of $E T_{h}$ and $T_{h}$ occured in October, which was a consequence of the drop in air temperature $\left(8.5^{\circ} \mathrm{C}\right)$ and water vapour deficit $(1.8 \mathrm{hPa})$. This month, compared to the entire summer half-year, showed the highest relative humidity $(>84 \%)$. Another factor limiting transpiration volume during that month was a gradual decrease in the life activity of reed, its aging (wilting) and necrosis (Kopcewicz 2012).

All parts of aquatic plants that are above water take part in transpiration. However, the most efficient transpiring organ is the leaf (Gumiński 1983). The rate of this process therefore depends on the number and size of leaves (Kacperska 2009). The biggest differences between the $T_{h}$ and $E_{O}$ were observed when the index LAI was significantly higher than $2.5 \mathrm{~m}^{2} \mathrm{~m}^{-2}$, and the total area of leaves in the reed bed was $80-100 \mathrm{dm}^{2}$. In the period of maximum development of the reed bed, transpiration was twofold higher than open water evaporation (Fig. 7).

The average common reed transpiration rate throughout the measurement period (May-October) was $1.91 \mathrm{dm}^{3} \mathrm{~m}^{-2} \mathrm{~d}^{-1}$, and for the period of the welldeveloped reed bed (June-September) it was $1.83 \mathrm{dm}^{3}$ $\mathrm{m}^{-2} \mathrm{~d}^{-1}$. From June to September, transpiration rate ranged from 59 to $146 \%$ of the average determined for that period. The abnormally high evaporation rate re- 

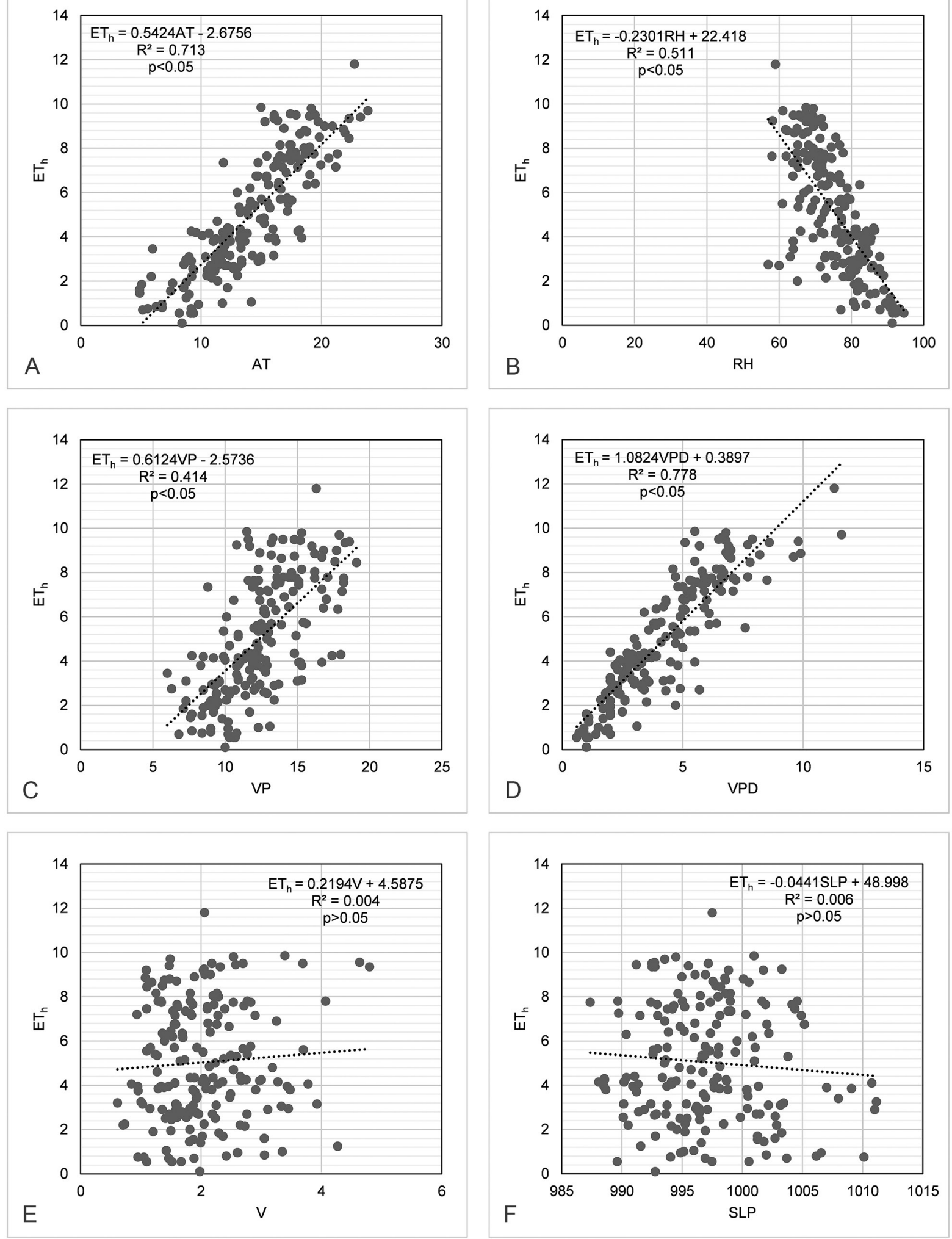

Fig. 5. Correlation between daily evapotranspiration totals and mean daily values: air temperature (A), relative humidity (B), water vapour pressure (C), water vapour deficit (D), wind velocity (E) and air pressure (F) at the Borucino weather station in the summers of 2014 and 2015 

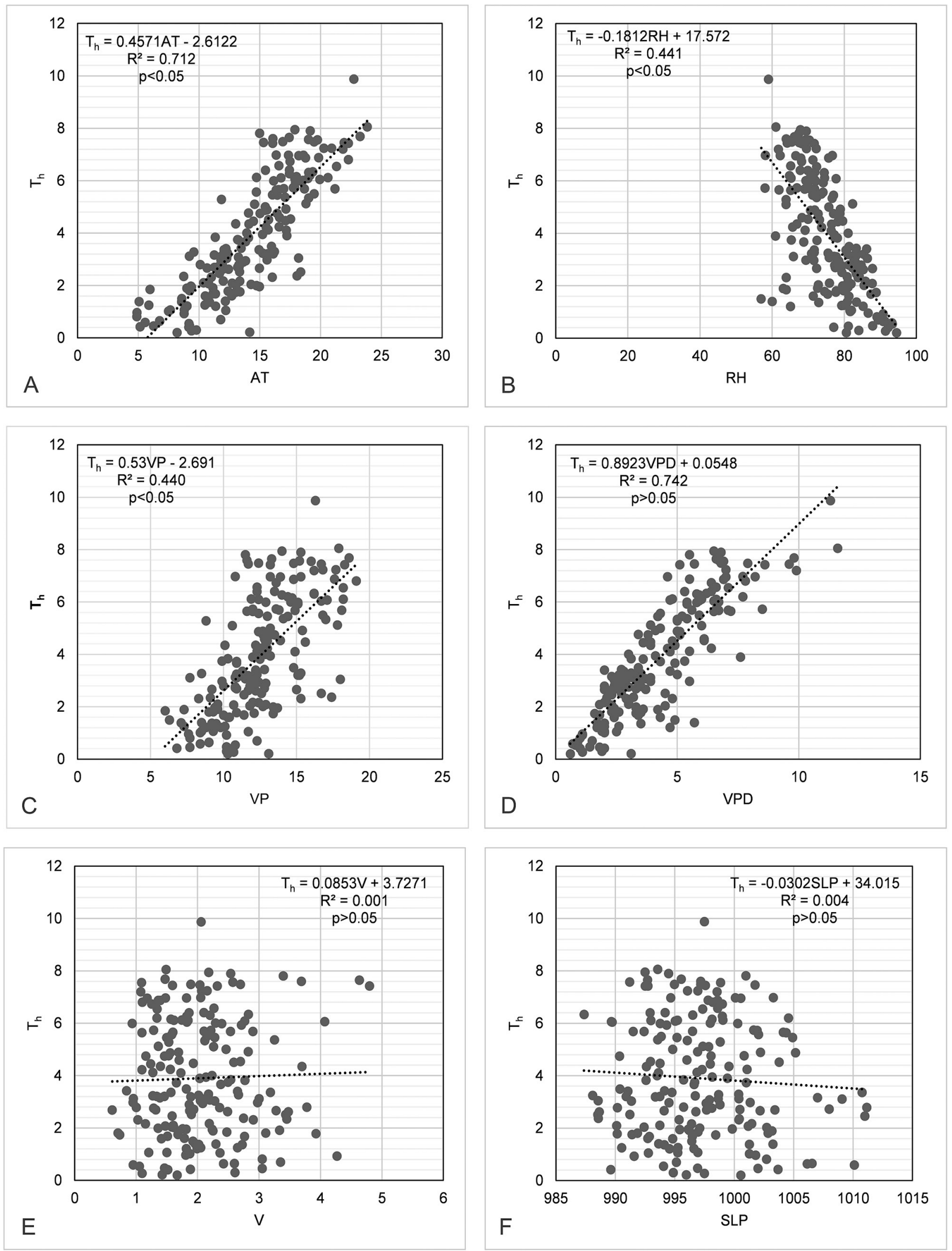

Fig. 6. Correlation between daily transpiration totals and mean daily values of: air temperature (A), relative humidity (B), water vapour pressure (C), water vapour deficit (D), wind velocity (E) and air pressure (F) at the Borucino weather station in the summers of 2014 and 2015 


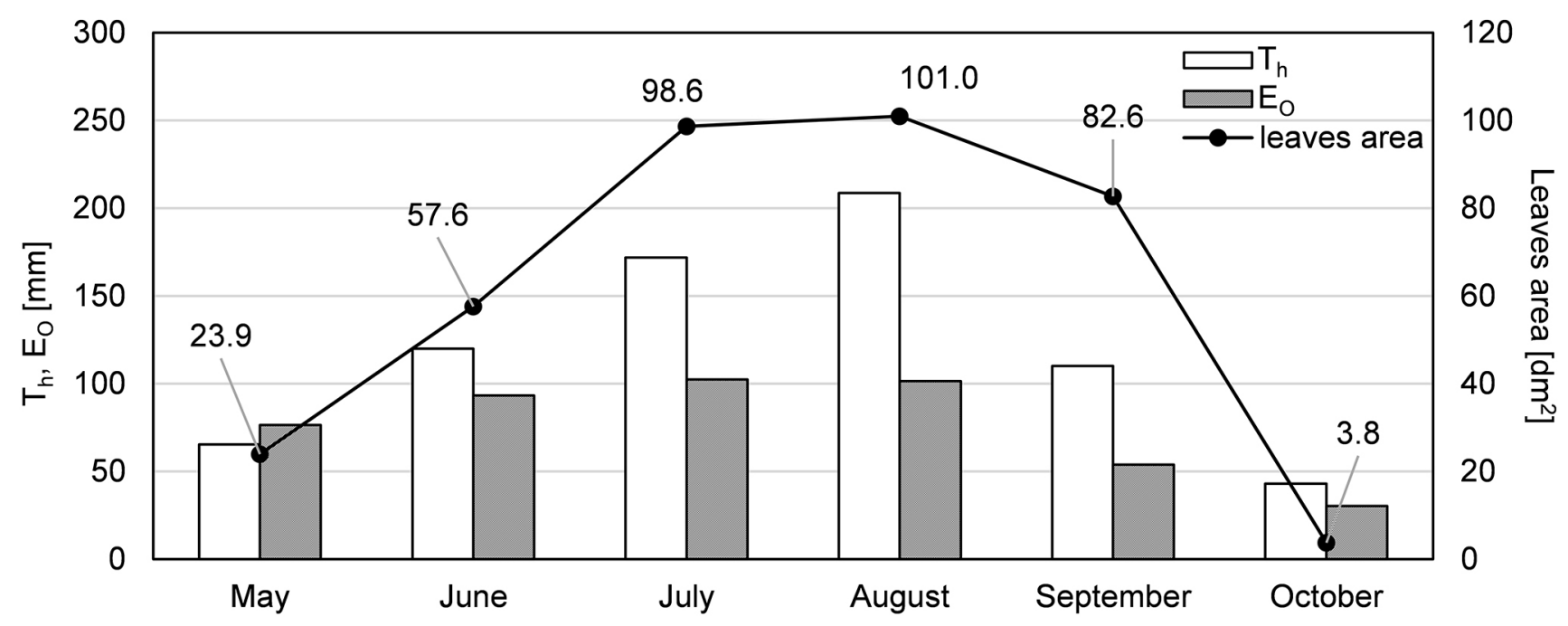

Fig. 7. Differentiation of common reed transpiration against leaf area changes in the vegetation cycle during the summers of 2014 and 2015 in Borucino

corded in October (500-690\% of the average) indicates its considerable overestimation. This may be due to: (i) transpiration overestimation following an underestimation of evaporation from the reed bed water surface (adoption of a fixed correlation $E_{h}=0.46 E_{O}$ ), (ii) low frequency of the leaf area measurements during reed aging, thus underestimating its actual value (leaf area measurements were performed in the third decade of October), (iii) a water capillary rise in already dead stems and evaporation from their surface. Underestimation of evaporation from the reed bed water surface may also be indicated by an increased transpiration rate in May, when the reed was just beginning to form (Table 2). Therefore, the results of transpiration rate meas- urements referring to June-September $\left(1.83 \mathrm{dm}^{3} \mathrm{~m}^{-2}\right.$ $\left.\mathrm{d}^{-1}\right)$ should be considered as most reliable.

In almost every month of the measurement period, transpiration exceeded open water evaporation $\left(T_{h} /\right.$ $\left.E_{O}>0\right)$. Only in May 2015 were these relationships reversed. The most marked differences between $T_{h}$ and $E_{O}$ were found in August to September 2015, when transpiration was higher than open water evaporation by 234.2 and $224.1 \%$, respectively. Throughout the entire measurement period $T_{h} / E_{O}$ was 1.6. This value is similar to that obtained by Sánchez-Carrillo et al. (2001) and more than twice as high as that specified by Bernatowicz et al. (1976) for the Masurian Lakeland (Table 4). The ratio of $T_{h} / E_{O}$ quoted in the latter paper appears

Table 4. Comparison of transpiration $\left(T_{h}\right)$ and evapotranspiration $\left(E T_{h}\right)$ rates and ratios of $T_{h} / E_{O}$ and $E T_{h} / E_{O}$ for common reed calculated with the use of various measurement methods. Ranges and mean values (in parentheses)

\begin{tabular}{|c|c|c|c|c|c|c|}
\hline \multicolumn{2}{|c|}{$T_{h}$} & \multicolumn{2}{|c|}{$E T_{h}$} & \multirow{2}{*}{$T_{h} / E_{o}$} & \multirow{2}{*}{$E T_{h} / E_{o}$} & \multirow{2}{*}{ Reference } \\
\hline $\mathrm{mm} \mathrm{d}^{-1}$ & $\mathrm{~mm} \mathrm{yr}^{-1}$ & $\mathrm{~mm} \mathrm{~d}^{-1}$ & $\mathrm{~mm} \mathrm{yr}^{-1}$ & & & \\
\hline $0.00-12.5(3.90)$ & $670-766(718)$ & $0.00-14.9(5.00)$ & $872-971(921)$ & $0.70-2.30(1.60)$ & $1.20-2.80(2.00)$ & This study \\
\hline \multirow[t]{4}{*}{1.22} & & & & & & Irmak et. al. (2013) \\
\hline & & & $(1346)$ & & $1.60-3.48(2.43)$ & Rösler et al. (2012) \\
\hline & & & & & $2.67-2.85$ & Xu and Ma (2011) \\
\hline & & $0.30-2.75$ & & & & Read et. al (2008) \\
\hline \multirow[t]{4}{*}{$7.10-7.70$} & $(1369)$ & & & $\begin{array}{c}1.10-2.40 \\
(1.50)\end{array}$ & & $\begin{array}{l}\text { Sanchez-Carrilo et al. } \\
(2001)\end{array}$ \\
\hline & 453-901 (721) & & $\begin{array}{c}824-1324 \\
(1101)\end{array}$ & $0.86-1.33(1.10)$ & $1.55-1.96(1.70)$ & Herbst and Kappen (1999) \\
\hline & & & & & 1.60 & Gilman and Newson (1982) \\
\hline & $195-345(293)$ & & $397-547(495)$ & $0.45-0.80(0.68)$ & $0.92-1.27(1.15)$ & Bernatowicz et al. (1976) \\
\hline $1.40-6.90$ & & & & & $(1.25)$ & Šmíd (1975) \\
\hline $7.70-7.90$ & & & & & & Květ (1973) \\
\hline $6.90-11.4$ & & & & & & Rychnovska (1973) \\
\hline & & $17.9-27.8^{1}$ & & & & Gavenčiak (1972) \\
\hline $12.2-13.7^{1}$ & $940-1100$ & & & & & Tuschl (1970) \\
\hline
\end{tabular}

\footnotetext{
1 - maximum values.
} 
to be significantly underestimated, which is indirectly indicated by the studies by Rösler et al. (2012). These authors determined the average ratio of $T_{h} / E_{O}$ as equal to 2.43 (Table 4). Even assuming overestimated reedcovered water evaporation as equal to open water evaporation (i.e. $E_{h}=E_{O}$ ), the average ratio of $T_{h} / E_{O}$ calculated from the measurements by Rösler et al. (2012) is $\sim 1.43$. Furthermore, studies by Herbst and Kappen (1999) confirm that the average annual value of the ratio is greater than 1 . Therefore, it can be assumed that during the growing season the relation of common reed transpiration to open water evaporation is described by the ratio $T_{h} / E_{O}=1.5-1.6$.

The real impact of reed bed evapotranspiration on the lake water balance can be specified from the ratio of $E T_{h} / E_{O}$. Its mean monthly values ranged from 1.2 to 2.8. Most research indicates an $E T_{h} / E_{O}$ ratio for common reed of $0.92-3.48$ (Table 4). The values of $E T_{h} / E_{O}$ obtained during the experiment are within this range. The mean ratio of 2.0 for the entire measurement period is similar to those provided by Herbst and Kappen (1999) as well as Rösler, et al. (2012). Particularly interesting is the comparison of the current research results with those obtained by Rösler et al. (2012) in Radzyń on Lake Sławskie. In both cases, the same measurement methods were used. Average evapotranspiration in the period of May-October in Radzyń (1346 mm) was 46\% higher than in Borucino. With the differences in open water evaporation up to $21 \%$, the average $E T_{h} / E_{O}$ ratio was 2.43 (Table 4 ). The larger $E T_{h} / E_{O}$ ratio established for Radzyń mainly reflects the regional diversity of climatic conditions. The Radzyń weather station is located in the Southern Greater Poland climatic region (Woś 1999). Compared with the region of Eastern Pomerania, in summer this region has an air temperature that is higher by $1.1^{\circ} \mathrm{C}$, and a humidity water vapour deficit greater by $1.0 \mathrm{hPa}$. Energy conditions of both regions are similar, and the average total radiation flux is 14.614.7 $\mathrm{MJ} \mathrm{m}^{-2} \mathrm{~d}^{-1}$ (Miara et al. 1987).

\section{Conclusion}

The research results showed that mean daily common reed transpiration between May and October was $3.9 \mathrm{~mm}$. Maximum daily transpiration values reached 12.1-12.5 mm. Decade values ranged from 7.5 to $71.9 \mathrm{~mm}$. The highest monthly transpiration total was observed in August ( $208.5 \mathrm{~mm})$, while the lowest in October $(42.8 \mathrm{~mm})$. During the growing season water losses to transpiration reach $872-971 \mathrm{~mm}$. The average transpiration rate, determined for the period of JuneSeptember, in conditions of the already well-developed reed bed, amounted to $1.83 \mathrm{dm}^{3} \mathrm{~m}^{-2} \mathrm{~d}^{-1}$.
The $T_{h} / E_{O}$ and $E T_{h} / E_{O}$ ratios established during the experiment remain within the ranges reported in most previous studies. The average $T_{h} / E_{O}$ ratio was 1.6 , and the $E T_{h} / E_{O}$ ratio was 2.0. These values indicate that in the growing season common reed transpiration is $60 \%$ higher than open water evaporation, and the total water loss to evapotranspiration from the reed bed twice exceeds open water evaporation.

\section{Acknowledgments}

This work was partially supported by the University of Gdańsk under project BW 538-G125-B213-16.

\section{References}

Baier W., 1968, Relationships between soil moisture, actual and potential evapotranspiration, Proc. of the Hydrology Symposium No. 6: Soil moisture,15-16 November 1967, Queen's Printer, Ottawa: 155-204.

Bernatowicz S., Leszczyński S., Tyczyńska S., 1976, The influence of transpiration by emergent plants on the water balance in lakes, Aquat.Bot., 2:275-288.

Choiński A., 2007, Limnologia fizyczna Polski (Physical limnology of Poland), Wydaw. UAM, Poznań, 547 pp.

Chunpin C., Jingcheng C., Lin B., 2002, Study on simple transpiration model and fitted measurement time for dominant plant at mudstone area in Taiwan, Proc. of the $12^{\text {th }}$ ISCO Conference. Vol. IV. Dynamic monitoring, forecasting and evaluation of soil erosion - Watershed management and development - Desertification control, 26-31 May, Beijing: 244-250

Devlin R.M., 1975, Plant physiology, Van Nostrand Company, New York, 600 pp.

Downing J.A., Prairie Y.T., Cole J., Duarte C.M., Tranvik J., Striegi R.G., McDowell W.H., Kortelainen P., Caraco N.F., Melack J.M., Middelburg J., 2006, The global abundance and size distribution of lakes, ponds, and impoundments, Limnol. Oceanogr. 51(5): 2388-2397.

Gavenčiak Š., 1972, Výskum strát vody evapotranspiráciou z vodných rastlín (Research on water loss by evapotranspiration from water plants), Vodohospod. Čas. 20: 16-32 (in Czech).

Gelbukh T.M., 1963, Evapotranspiration from overgrowing reservoirs, IAHS Publ. No. 62, Wallingford: 87.

Gilman K., Newson M.D., 1982, The Anglesey Wetlands study. The final report of a three-year study by the NERC Institute of Hydrology, Inst. Hydr., Wallingford, 113 pp.

Gumiński S., 1983, Ogólna fizjologia roślin (General plant physiology), PWN, Warszawa, 411 pp.(in Polish).

Hanami Y., 1974, Effects of environmental factors upon transpiration, Acta Hort. 39: 183-196.

Herbst M., Kappen L., 1999, The ratio of transpiration versus evaporation in reed belt as influenced by weather conditions, Aquat. Bot. 63: 113-125. 
Irmak S., Kabenge I., Rudnick D., Knezevic S., Woodward D., Moravek M., 2013, Evapotranspiration crop coefficients for mixed riparian plant community and transpiration crop coefficients for common reed, cottonwood, and peach-leaf willow in the Platte River basin, NebraskaUSA, J. Hydrol. 481:177-190.

Kacperska A., 2009, Gospodarka wodna (Water management), [in:] Kopcewicz J., Lewak S. (eds) Fizjologia roślin (Plant physiology), PWN, Warszawa: 36-57 (in Polish).

Kiendl J., 1953, Zum Wasserhalt des Phragmitetum Communis und Glycerictum aquatiacac, Ber. Deutsch. Bot. Ges. 66: 246-263.

Kopcewicz J., 2012, Starzenie się roślin (Aging plants), [in:] Kopcewicz J., Lewak S. (eds) Fizjologia roślin (Plant physiology), PWN, Warszawa: 587-606 (in Polish).

Kowalczyk V., 1993, Zróżnicowanie zarastania jezior w zlewniach w obrębie wydzielonych Pojezierzy (Differentiation of lakes overgrowing in the catchment areas within the specified lakelands) [masterthesis], IGF UAM, Poznań.

Květ J., 1973, Transpiration of South Moravian Phragmites communis, [in:] Květ J. (ed.) Littoral of the Nesyt Fishpond, Studie ČSAV 15, Academia, Praha: 143-146.

Ławniczak A.E., 2010, Overgrowing of two polymictic lakes in Central-Western Poland, Limnol. Rev. 10(3-4): 147156.

Malinowska M., 2010, Woda $\mathrm{w}$ atmosferze (Water in the atmosphere), [in:] Malinowska M. (ed), Przewodnik do ćwiczeń z meteorologii i klimatologii (Exercise guide for meteorology and climatology), Wydaw. UG, Gdańsk: 75-96. (in Polish).

Miara K., Paszyński J., Grzybowski J., 1987, Zróżnicowanie przestrzenne bilansu promieniowania na obszarze Polski (Spatial distribution of radiation balance in Poland), Prz. Geogr. 59(4): 487-509 (in Polish, English summary).

Miętus M., Filipiak J., Owczarek M., Jakusik E., 2005, Zmienność warunków opadowych w rejonie polskiego wybrzeża Morza Bałtyckiego w świetle kwantylowej klasyfikacji opadowej (The variability of pluvial conditions in the Baltic Sea Coast: results based on the quantile classification), Mat. Bad. IMGW, Meteorologia 37: 3-59 (in Polish, English summary)

Miętus M., Owczarek M., Filipiak J., 2002, Warunki termiczne na obszarze Wybrzeża i Pomorza w świetle wybranych klasyfikacji (Thermal conditions on the Polish Coast and the Pomerania Region in view of selected classifications), Mat. Bad. IMGW, Meteorologia 36: 3-56 (in Polish).

Otis C.H., 1914, The transpiration of emersed water plants: its measurement and relationships, Bot. Gaz. 58: 457-494.

Ptak M., 2013, Zmiany powierzchni i batymetrii wybranych jezior Pojezierza Pomorskiego (Changes in the area and bathymetry of selected lakes of the Pomeranian Lake District), Pr. Geogr. IGiGP UJ 133: 61-76 (in Polish, English summary).

Pieńkowski P., Kupiec M., 2001, Proces zarastania Jeziora Świdwie i zmiany w użytkowaniu jego otoczenia od początku XIX do końca XX wieku (Process of overgrowing of Świdwie lake and changes in its surroundings land use from the beginning of the 19th century until the end of the 20th century), Zesz. Nauk. PZ, Inż. Środ. 11: 265277 (in Polish, English summary).

Price J.S., 1994, Evapotranspiration from a lakeshore Typha marsh on Lake Ontario, Aquat. Bot. 48: 261-272.

Šmid P., 1975, Evaporation from a reed swamp, J. Ecol. 63: 299-309.

Sánchez-Carrillo S., Alvarez-Cobelas M., Angeler D.G, Benítez M., 2001, A Simple method for estimating water loss by transpiration in wetlands, Hydrol. Sci. J. 46: 537-552.

Snyder R.L., Boyd C.E., 1987, Evapotranspiration by Eichhomia crassipes (Mart.) Solms and Typha latifolia L., Aquat. Bot. 27(3): 217-227.

Read K.E.,. Hedges P.D., Fermor P.M., 2008, Monthly evapotranspiration coefficients of large reed bed habitats in the United Kingdom, [in:] Vymazal J. (ed.), Wastewater treatment. Plant dynamics and danagement in donstructed and natural wetlands, Springer Science \& Business Media B.V., Dordrecht: 99-109.

Rojecki A., 1959, Tablice psychrometryczne (Psychrometric tables), Wydaw. Telekom., Warszawa, 211 pp. (in Polish).

Rösler A., Chmal M., Chmal T., 2012, Evapotranspiration from a reed bed as example of oasis effect, [in:] Grześkowiak A., Nowak B., Grzonka B. (eds), Anthropogenic and natural transformations of lakes. Vol. 6, Wyd. IMGW-PIB, Poznań: 131-135.

Rychnovska M., 1973, Some physiological features of water balance in littoral and terrestrial Phragmites communis Trin., [in:] Květ J. (ed.) Littoral of the Nesyt Fishpond, Studie ČSAV 15, Academia, Praha: 147-151.

Tuschl P., 1970, Die Transpiration von Phragmites communis im geschlossenen Bestand des Neusiedler Sees, Wiss. Arb. Burgenland 44: 126-186.

Uryvaev V.A., 1953, Eksperimentalnye issledovania na Valdae (Experimental research in Valdai), Gidrometeoizdat., Leningrad, 232 pp. (in Russian).

Wetzel R. G., 2001, Limnology. Lake and river ecosystems, Academic Press, San Diego, 1066 pp.

Woś A., 1999, Klimat Polski (Climate of Poland), PWN, Warszawa, 301 pp. (in Polish).

Xu S., Ma T., 2011, Evapotranspiration observation and data analysis in reed swamp wetlands, IAHS Publ. No. 344, Wallingford: $239-244$. 